\title{
Hormonal, renal, and autonomic nerve factors involved in the excretion of sodium and water during dynamic salt and water loading in hypoxaemic chronic obstructive pulmonary disease
}

\author{
A G Stewart, J C Waterhouse, C G Billings, P H Baylis, P Howard
}

\begin{abstract}
Background - Some patients with hypoxaemic chronic obstructive pulmonary disease (COPD) develop sodium and water retention and a subclinical autonomic neuropathy. The possibility that these might be associated has been investigated. Methods - The ability of 24 patients with COPD to excrete a $6 \mathrm{ml} / \mathrm{kg} 2 \cdot 7 \%$ intravenous saline or $15 \mathrm{ml} / \mathrm{kg}$ oral water load was studied and changes in plasma electrolyte levels, osmolality, plasma aldosterone and vasopressin levels, urinary volume and sodium content, glomerular filtration rate, renal blood flow, and cardiovascular autonomic nerve function were measured. Patients were divided into groups of eight: those in group $A$ (controls) had mild COPD with a $\mathrm{PaO}_{2}$ of $>9 \mathrm{kPa}$ and no oedema, patients in group $B$ were more hypoxaemic but had never been oedematous, whilst those in group $C$ were hypoxaemic and mildly oedematous at the time of the study.
\end{abstract}

Results - Patients in groups B and C excreted less sodium and water during saline loading and a lesser proportion of the water load. Patients in group $C$ had a reduction in renal blood flow and glomerular filtration rate and all had a subclinical autonomic neuropathy, which was also found in three patients in group B. Their plasma aldosterone level was raised but did suppress appropriately on saline loading. Vasopressin levels were abnormally raised for the osmolality in patients in group $\mathbf{C}$ and in those with autonomic dysfunction throughout the water load and at 240 minutes after the salt load. Sodium and urine excretion was highly correlated with autonomic dysfunction, aldosterone levels at time zero, and renal blood flow. The 11 patients with autonomic dysfunction were more likely to be oedematous, more hypoxaemic, excreted much less urine and sodium, had lower glomerular filtration rate and renal blood flow, and higher aldosterone and vasopressin levels than the remaining patients.

Conclusions - In patients with COPD the inability to excrete sodium and water is multifactorial. This is the first study to show that autonomic dysfunction is at least associated and might play an important part in the impaired sodium and water homeostasis seen in patients with severe COPD.

(Thorax 1995;50:838-845)

Keywords: autonomic neuropathy, chronic obstructive pulmonary disease, sodium and water excretion.

The development of sodium and water retention in hypoxaemic patients with chronic obstructive pulmonary disease (COPD) implies a poor prognosis. ${ }^{1}$ The cause of this retention is unclear, but it is not due to cardiac failure since cardiac output is maintained or even increased. ${ }^{23}$

Abnormalities in vasopressin secretion and activation of the renin angiotensin aldosterone system have been identified in oedematous hypercapnic patients with COPD. ${ }^{4-6}$ The raised aldosterone levels may contribute to sodium retention and the increased levels of vasopressin may cause hyponatraemia and water retention. However, we have recently shown that inhibition of angiotensin converting enzyme, which reduces aldosterone levels to normal, does not improve sodium excretion in these patients. ${ }^{7}$ It is possible that the raised hormone levels, rather than being the cause of oedema in cor pulmonale, are an effect of disease processes such as reduction in renal blood flow, increased sympathetic stimulation, or even the effect of diuretics used to treat the oedema.

Sodium and water homeostasis is a complex interaction of many factors. The autonomic nervous system is important. Alterations in autonomic tone affects hormonal levels, ${ }^{8}$ renal blood flow, ${ }^{9}$ and is associated with oedema formation in patients with alcoholic cirrhosis. ${ }^{10}$

We have recently shown that patients with COPD have a subclinical autonomic neuropathy, ${ }^{11} 12$ the severity of which correlates with their degree of hypoxaemia. We hypothesised that such a neuropathy might be associated with the development of oedema and sodium and water retention in these patients. We therefore investigated the ability of 24 patients with varying severities of COPD to excrete both saline and water loads whilst measuring their hormonal responses, glomerular filtration rate, renal blood flow, and cardiovascular autonomic nerve function. 
Methods

SUBJECTS

Twenty four consenting patients with stable COPD were chosen from the chest clinic. Patients with known ischaemic or valvular heart disease, hypertension, liver disease, renal disease, hormonal disorder, or diabetes were excluded.

All patients were stable at the time of assessment. No patient had had an infective exacerbation in the preceding month. Diuretics were stopped for three days in the five patients who were receiving them, and oxygen therapy (five patients) was discontinued on the day of testing. Patients used their $\beta_{2}$ agonists as required only on awakening and then did not use them until the end of the test. No patient was on oral prednisolone or an angiotensin converting enzyme inhibitor.

Eight patients with COPD who had never suffered from peripheral oedema or documented hypoxaemia of $<9 \mathrm{kPa}$ were used as controls (group A). Eight patients with more severe COPD with more severe hypoxaemia who had never suffered from oedema or raised jugular venous pulse made up group $B$, and group $\mathrm{C}$ consisted of eight further patients with severe COPD who had stable oedema at the time of assessment.

The study was approved by the ethical committee of the Sheffield Health Authority. Patients gave consent freely after the aims and requirements of the study had been explained.

\section{STUDY DETAILS}

Each of the 24 consenting volunteers received at one week intervals the water load, DTPA renogram/autonomic function tests, and then the salt load. Before the experiment the patients ate a normal diet.

\section{Hypertonic saline load}

On the day of the salt or water load the patients were fasted overnight and brought by taxi to the laboratory at 09.00 hours. They were weighed, spirometric tests were performed (Vitalograph Compact) and urine was collected for measurement of osmolality and electrolyte levels. Throughout the experiment blood pressure (sphygmomanometer), pulse, and oxygen saturation were recorded by a Ohmeda Biox 3700 pulse oximeter.

Patients remained seated throughout the salt load test. Blood samples for measurement of urea electrolytes (Technicon SMAC analyser) and osmolality (Advance osmometer 2WII) were collected into serum tubes and plasma hormone levels collected into EDTA tubes. The EDTA tubes were immediately centrifuged and the plasma removed and frozen at $-20^{\circ} \mathrm{C}$ until assayed. Samples were taken at $-30,0$, $60,120,180$, and 240 minutes after the saline infusion. Between time 0 and 60 minutes each subject received an intravenous infusion of $2.7 \%$ saline $(450 \mathrm{mmol} / \mathrm{l})$ at a rate of $0.1 \mathrm{ml} /$ $\mathrm{kg} / \mathrm{min}$. After four hours arterial blood gas estimations were made and the patients emp- tied their bladders, the urine volume was noted, and urine sodium and creatinine levels and osmolality were measured.

\section{Oral water load}

The same procedure was used on the water load day, the only exception being that the patients drank $15 \mathrm{ml} / \mathrm{kg}$ body weight over the 60 minute period. Wherever possible the patients remained seated. This involved transfer to a commode or use of a urinary bottle where appropriate. Micturition was encouraged after venesection rather than before.

Creatinine clearance was calculated over the 4.5 hours of the test and used as a measure of the glomerular filtration rate. Filtered sodium ( $\mathrm{mmol} / \mathrm{min}$ ) was calculated by multiplying the glomerular filtration rate by the plasma sodium concentration. Fractional sodium reabsorption was calculated by dividing excreted sodium ( $\mathrm{mmol} / \mathrm{min}$ ) by the filtered sodium and subtracting from 1; the fraction was expressed as a percentage. Free water clearance (= $\mathrm{Uv}-(\mathrm{Uosm} \times \mathrm{Uv} /$ Posm) $)$ was calculated using an average of the plasma osmolalities during the test (Posm) and the end urine osmolality (Uosm) and the minute urine volume (Uv), negative values being the renal reabsorption of water $(\mathrm{ml} / \mathrm{min})$.

\section{Hormone analysis}

Plasma aldosterone levels were measured by SB-ALDO radioimmunoassay kits (CIS Bio International, Cedex, France) according to the manufacturers' instructions. The normal ranges quoted for the kits are $15-150 \mathrm{pg} / \mathrm{ml}$ when supine and $35-300 \mathrm{pg} / \mathrm{ml}$ when upright. The kit sensitivity is $15 \mathrm{pg} / \mathrm{ml}$. Vasopressin was measured by a recognised radioimmunoassay method $^{13}$ which had an interassay coefficient of variation of 15.3 and an intra-assay coefficient of variation of $9.7 \%$ with a limit of detection of $0.3-0.8 \mathrm{pmol} / 1$ depending on sample size.

Renal blood flow and glomerular filtration rate Glomerular filtration rate was also measured during the technetium-99m labelled diethylene triamine pentaacetate ( $99 \mathrm{mTc}-\mathrm{DTPA})$ renogram by venous plasma sampling at 120,180 , and 240 minutes after the injection. Renal blood flow was measured by the method described by Peters et al. ${ }^{14}$ This technique allows organ blood flow to be calculated by the principle of fractionation of the cardiac output and is applicable with any recirculating gamma emitting tracer. Results were expressed as a percentage of cardiac output.

\section{Cardiovascular autonomic function testing}

Cardiovascular autonomic nervous system function was measured on the day of the renogram as previously described. ${ }^{11215}$ Briefly, this included the heart rate response to a valsalva manoeuvre where the maximum heart rate 
Table 1 Patient characteristics, renal function and autonomic function (mean (SD))

\begin{tabular}{|c|c|c|c|}
\hline & $\begin{array}{l}\text { Group A (control) } \\
(n=8)\end{array}$ & $\begin{array}{l}\text { Group B (hypoxic) } \\
(n=8)\end{array}$ & $\begin{array}{l}\text { Group } C \text { (oedema) } \\
(n=8)\end{array}$ \\
\hline $\begin{array}{l}\text { Age (years) } \\
\text { Height }(\mathrm{cm}) \\
\text { Weight }(\mathrm{kg}) \\
\text { On diuretics }\end{array}$ & $\begin{array}{c}66 \cdot 6(6 \cdot 3) \\
167 \cdot 7(6 \cdot 8) \\
77 \cdot 0(8 \cdot 7) \\
0\end{array}$ & $\begin{array}{r}64 \cdot 8(4 \cdot 2) \\
158 \cdot 1(5 \cdot 7) \\
81 \cdot 4(8 \cdot 0) \\
1\end{array}$ & $\begin{array}{c}71 \cdot 2(3 \cdot 8) \\
155 \cdot 4(5 \cdot 8)^{* * *} \\
69 \cdot 2(17 \cdot 3) \\
4\end{array}$ \\
\hline $\begin{array}{l}\mathrm{FEV}_{1}(\% \text { predicted }) \\
\mathrm{FVC}(\mathrm{l}) \\
\mathrm{PaO}_{2}(\mathrm{kPa}) \\
\mathrm{PaCO}_{2}(\mathrm{kPa})\end{array}$ & $\begin{array}{l}41 \cdot 6(14) \\
3 \cdot 4(0 \cdot 8) \\
9 \cdot 5(0 \cdot 6) \\
5 \cdot 4(0 \cdot 9)\end{array}$ & $\begin{array}{l}37 \cdot 3(10 \cdot 8) \\
2 \cdot 2(0 \cdot 8) \\
7 \cdot 5(0 \cdot 7) \\
6 \cdot 4(1 \cdot 0)\end{array}$ & $\begin{array}{l}27(5)^{*} \\
1 \cdot 8(0 \cdot 6)^{*} \\
6 \cdot 9(0 \cdot 7)^{* * *} \\
6 \cdot 1(0 \cdot 9)\end{array}$ \\
\hline $\begin{array}{l}\text { GFR (by DTPA renogram) } \mathrm{ml} / \mathrm{min} \\
\mathrm{RBF} \text { (as \% cardiac output) }\end{array}$ & $\begin{array}{l}80(15) \\
17 \cdot 4(3 \cdot 3)\end{array}$ & $\begin{array}{l}77(13) \\
16 \cdot 2(5 \cdot 8)\end{array}$ & $\begin{array}{l}62(12)^{*} \\
12 \cdot 1(3 \cdot 5)^{*}\end{array}$ \\
\hline $\begin{array}{l}\text { Autonomic function } \\
\text { Valsalva ratio } \\
\text { I-E heart rate difference } \\
30: 15 \text { ratio } \\
\text { Postural BP fall }(\mathrm{mm} \mathrm{Hg}) \\
\text { Autonomic score }\end{array}$ & $\begin{array}{l}1 \cdot 34(0 \cdot 17) \\
12 \cdot 6(5 \cdot 5) \\
1.09(0 \cdot 05) \\
12.4(1 \cdot 2) \\
1 \cdot 4(1 \cdot 1)\end{array}$ & $\begin{array}{l}1 \cdot 25(0 \cdot 18) \\
9 \cdot 5(2 \cdot 1) \\
1 \cdot 05(0 \cdot 02) \\
10 \cdot 4(8 \cdot 9) \\
2 \cdot 9(2 \cdot 0)\end{array}$ & $\begin{array}{l}1 \cdot 11(0 \cdot 03)^{* *} \\
5 \cdot 7(2 \cdot 2)^{* *} \\
1 \cdot 00(0 \cdot 02)^{* * *} \\
15 \cdot 0(8 \cdot 7) \\
5 \cdot 6(0 \cdot 7)^{* * *}\end{array}$ \\
\hline $\begin{array}{l}\text { Comparison of groups during } 2 \cdot 7 \% \text { saline loading: } \\
\text { Volume of urine excreted }(\mathrm{ml}) \\
\text { Sodium excretion }(\mathrm{mmol}) \\
\text { \% sodium load excreted } \\
\text { Fractional sodium reabsorbed } \\
\text { Free water clearance }(\mathrm{ml} / \mathrm{min}) \\
\text { Urine (sodium) start }(\mathrm{mmol} / \mathrm{l})\end{array}$ & $\begin{array}{l}379(100) \\
78.8(19 \cdot 8) \\
37.9(8.9) \\
97.5(0.8) \\
-1 \cdot 8(0.5) \\
130(57)\end{array}$ & $\begin{array}{l}324(90) \\
56 \cdot 8(19 \cdot 1) \\
26(8 \cdot 9) \\
98 \cdot 3(0 \cdot 5) \\
-1 \cdot 2(0 \cdot 4) \\
129(47)\end{array}$ & $\begin{array}{l}216(67)^{* *} \\
34 \cdot 1(10)^{* * *} \\
18(5 \cdot 6)^{* * *} \\
98 \cdot 6(0 \cdot 5)^{*} \\
-0 \cdot 8(0 \cdot 2)^{* * *} \\
113(32)\end{array}$ \\
\hline $\begin{array}{l}\text { Comparison of groups during } 15 \mathrm{ml} / \mathrm{kg} \text { oral water loading: } \\
\text { Volume urine excreted }(\mathrm{ml}) \\
\% \text { water load excreted } \\
\text { Free water clearance }(\mathrm{m} / \mathrm{min}) \\
\text { Urine osmolality at end (mosmol) }\end{array}$ & $\begin{array}{c}1003(324) \\
88(30) \\
0.5(0.9) \\
251(73)\end{array}$ & $\begin{array}{c}679(111) \\
60(16) \\
0.4(0.5) \\
226(62)\end{array}$ & $\begin{array}{c}503(190)^{* *} \\
52(24)^{*} \\
-0 \cdot 3(0 \cdot 3)^{*} \\
356(82)^{*}\end{array}$ \\
\hline
\end{tabular}

$\mathrm{FEV}_{1}=$ forced expiratory volume in one second; $\mathrm{FVC}=$ forced vital capacity; $\mathrm{PaO}_{2}, \mathrm{Paco}_{2}=$ arterial oxygen and carbon dioxid tensions; $\mathrm{GFR}=$ glomerular filtration rate; $\mathbf{R B F}=$ renal blood flow.

${ }^{*} \mathrm{p}<0.05,{ }^{* *} \mathrm{p}<0.01,{ }^{* * *} \mathrm{p}<0.001$ comparing all three groups by analysis of variance.

during the valsalva is divided by the minimum heart rate on valsalva release (normal $>1 \cdot 20$, abnormal $<1 \cdot 11$ ), heart rate difference between inspiration and expiration during deep breathing (I-E difference, normal $>11$ beats $/ \mathrm{min}$, abnormal $<8$ ), and the heart rate response to standing from a supine position (the ratio of the RR interval at beat 30 compared with that at beat 15 after standing (30:15 ratio) which is normal if $>1.03$ and abnormal if $<1.01$ ). Postural systolic blood pressure fall was also recorded during this last test (normal $<10 \mathrm{~mm} \mathrm{Hg}$, abnormal $>30 \mathrm{~mm} \mathrm{Hg}$ ). All four tests were scored 0 if normal, 1 if borderline, and 2 if abnormal to give a combined autonomic score out of $8 .{ }^{12}$ Scores of $>3$ suggest an autonomic neuropathy.

\section{REPEATABILITY OF THE TESTS}

Repeatability of the DTPA renograms and the saline load experiment was carried out in eight patients with a forced expiratory volume in one second $\left(\mathrm{FEV}_{1}\right)$ of $0.79-2.001, \mathrm{PaO}_{2}$ of $7 \cdot 2-11 \cdot 0 \mathrm{kPa}$, and $\mathrm{PaCO}_{2}$ of $4 \cdot 5-7 \cdot 4 \mathrm{kPa}$. Clinical status, spirometric values, and arterial blood gas tensions were similar on these two occasions 1-3 months apart.

\section{DATA ANALYSIS}

Reproducibility was assessed by the correlation of repeatability. ${ }^{16}$ Groups of patients were compared by analysis of variance with Scheffes test. Multivariate correlation analysis of the parameters measured was performed. Stepwise multiple regression analysis was used to assess the importance of renal blood flow, glomerular filtration rate, aldosterone and vasopressin levels, and autonomic function on urinary volume and sodium excretion.

\section{Results}

With the exception of aldosterone levels at times 180 and 240 minutes, all results from the saline loading and DTPA renograms were repeatable with an acceptable coefficient of repeatability for sodium excretion, renal function, plasma electrolytes, and osmolality (results with editor).

The groups were similar for age and weight, although groups $B$ and $C$ were shorter. $\mathrm{FEV}_{1}$, glomerular filtration rate and renal blood flow were corrected for this. Arterial oxygen tensions were significantly lower in the oedematous group $(p<0.001)$ but, surprisingly, there was no difference in $\mathrm{PaCO}_{2}$ between the groups. Likewise, lung function $\left(\mathrm{FEV}_{1}\right.$ as \% of predicted) was also lowest in the oedematous group $C(p<0.05)$.

All patients in the oedematous group $C$ had evidence of a subclinical autonomic neuropathy $(p<0.001)$. Three patients in group B also had a definitely abnormal autonomic score. The heart rate response to standing (30:15 ratio) was the most individually discriminatory test, the results between the groups being significant $(p<0.001)$. Both glomerular filtration rate and renal blood flow were significantly different $(p<0.05)$ between the groups, being particularly low in group C (table 1).

During dynamic saline loading the urine volume excreted was significantly lower in group $B$ and even worse in group $C(p<0.01)$. The final urine sodium excretion, in absolute units and as a percentage of the saline load infused, was significantly different between the groups $(p<0.001)$, the oedematous group $C$ excreting half the load excreted by the control group $\mathrm{A}$. A greater fraction of the filtered sodium was reabsorbed in the more oedematous groups $(p<0.05)$. Free water reabsorption was significantly different $(p<0.001)$ between all groups. The oedematous group $\mathrm{C}$ were least 
able to excrete a concentrated urine. There was no difference between the groups in terms of serum sodium levels or osmolality (fig 1). raised at times -30 and 0 minutes before the infusion in group $\mathrm{C}$, but the levels did suppress appropriately and, although the aldosterone levels in this group were higher than in the other two groups, the difference was not significant (fig 1).

Likewise, plasma vasopressin levels were insignificantly raised in group C. In all groups
Plasma aldosterone levels were significantly

the saline infusion-induced rise in osmolality caused an appropriate rise in vasopressin (fig 1) which was greatest in patients in group $C$ in whom the level of vasopressin was inappropriately raised for the level of serum osmolality at 240 minutes (fig 5). During the dynamic oral water load the urine volume excreted was least in group $\mathrm{C}(\mathrm{p}<0 \cdot 01)$ (table 1$)$. Serum osmolality responses were similar whilst aldosterone and vasopressin (fig 2) were insignificantly higher in patients in group C.

Eleven patients had evidence of a subclinical
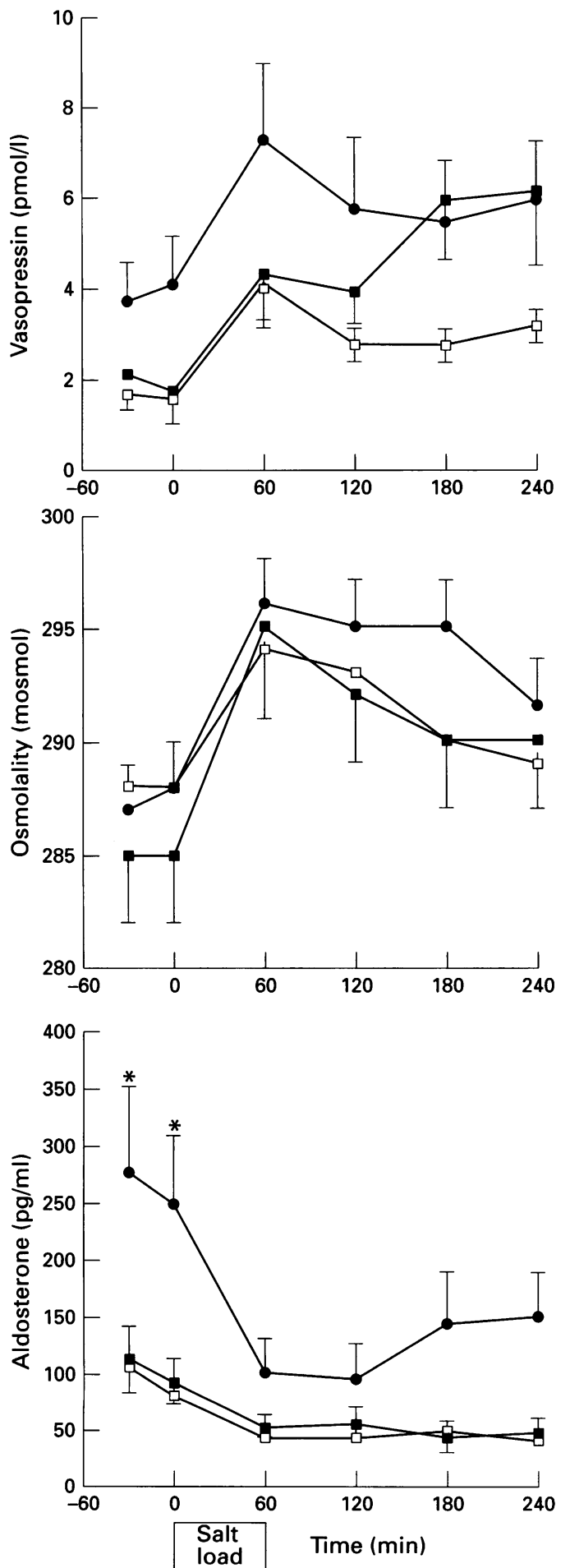

Figure 1 Mean (SE) plasma levels of aldosterone and vasopressin and serum osmolality during saline loading in patients with COPD. $\square=$ control group $A, \square=$ nonoedematous group $B, \quad=$ oedematous group $C .{ }^{*} p<0.05$.
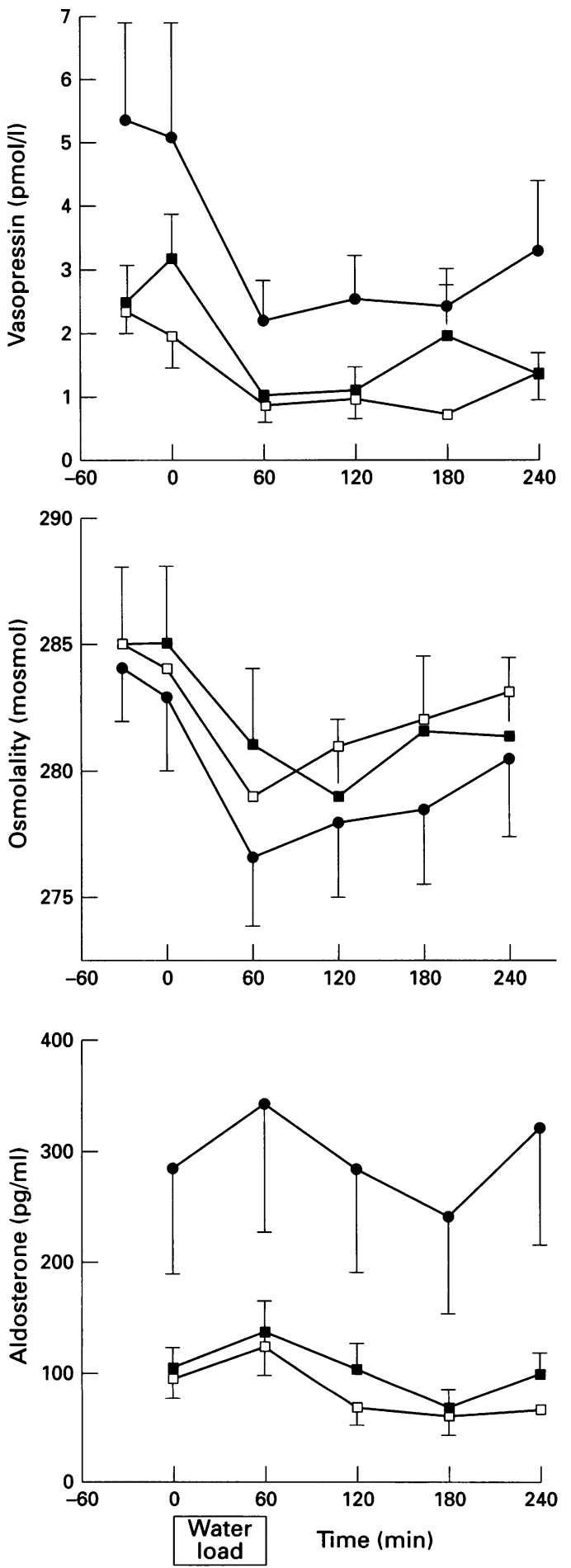

Figure 2 Mean (SE) plasma levels of aldosterone and vasopressin and serum osmolality during oral water loading in patients with COPD. $\square=$ control group $A$, $=$ non-oedematous group $B, O=$ oedematous group $C$. 
Table 2 Comparison of mean (SD) values in patients with and without evidence of a subclinical autonomic neuropathy

\begin{tabular}{lcc}
\hline Parameter & $\begin{array}{c}\text { Normal autonomic } \\
\text { function } \\
(n=13)\end{array}$ & $\begin{array}{c}\text { Subclinical autonomic } \\
\text { neuropathy } \\
(n=11)\end{array}$ \\
\hline Age (years) & $66(6)$ & $69(5)$ \\
Height (cm) & $168(7)$ & $155(6)^{*}$ \\
Weight (kg) & $80(9)$ & $71(15)$ \\
Oedema & None & 8 \\
$\mathrm{FEV}_{1}(\%$ predicted) & $40(12)$ & $30(10)^{*}$ \\
$\mathrm{PaO}_{2}(\mathrm{kPa})$ & $8 \cdot 9(1 \cdot 0)$ & $6 \cdot 9(0 \cdot 7)^{* * *}$ \\
$\mathrm{PaCO}_{2}(\mathrm{kPa})$ & $5 \cdot 8(1 \cdot 0)$ & $6 \cdot 1(0 \cdot 9)$ \\
& & \\
Results during saline loading: & $353(96)$ & $240(89)^{*}$ \\
Urine volume (ml) & $32(10)$ & $19 \cdot 5(10)^{* *}$ \\
$\%$ sodium load excreted & $1 \cdot 6(0 \cdot 5)$ & $-0 \cdot 9(0 \cdot 4)^{* *}$ \\
Free water clearance (ml/min) & $80(14)$ & $65(14)^{*}$ \\
GFR (ml/min) & $17 \cdot 5(4 \cdot 3)$ & $12 \cdot 6(4 \cdot 3)^{*}$ \\
RBF (\% cardiac output) & & \\
Results during oral 15 ml/kg water load: & $76(29)$ & $56(23)^{*}$ \\
$\%$ water load excreted & $0 \cdot 5(0 \cdot 8)$ & $-0 \cdot 1(0 \cdot 4)^{*}$ \\
Free water clearance (ml/min) & $240(74)$ & $324(89)^{*}$ \\
Urine osmolality at end (mosmol) & &
\end{tabular}

$\mathrm{FEV}_{1}=$ forced expiratory volume in one second $\mathrm{PaO}_{2}, \mathrm{PaCO}_{2}=$ arterial oxygen and carbon dioxide tensions; GFR = glomerular filtration rate; $\mathrm{RBF}=$ renal blood flow.

${ }^{*} \mathrm{p}<0 \cdot 05,{ }^{* *} \mathrm{p}<0.01,{ }^{* * *} \mathrm{p}<0.001$ comparing groups by the Mann-Whitney $\mathrm{U}$ test. autonomic neuropathy (table 2). They were more likely to be oedematous (eight cases), had worse lung function $(\mathrm{p}<0.05)$, were more hypoxaemic $(\mathrm{p}<0.001)$ but not hypercapnic, excreted less of the sodium load $(p<0.01)$ and water load $(\mathrm{p}<0.05)$, and their glomerular filtration rate and, particularly, their renal blood flow were lower. Aldosterone levels were raised at rest before the saline load but responded appropriately to the challenge and were insignificantly higher for the rest of the experiment (fig 3). Likewise, their vasopressin levels were higher, rose further as osmolality increased, and remained high at the end of the experiment despite a falling serum osmolality (figs 4 and 5). During water loading the vasopressin levels were higher in the patients with autonomic dysfunction group (fig 4). There was good correlation between autonomic dysfunction and sodium and urine excretion (table 3).

Stepwise multiple regression analysis of factors influencing sodium excretion during salt
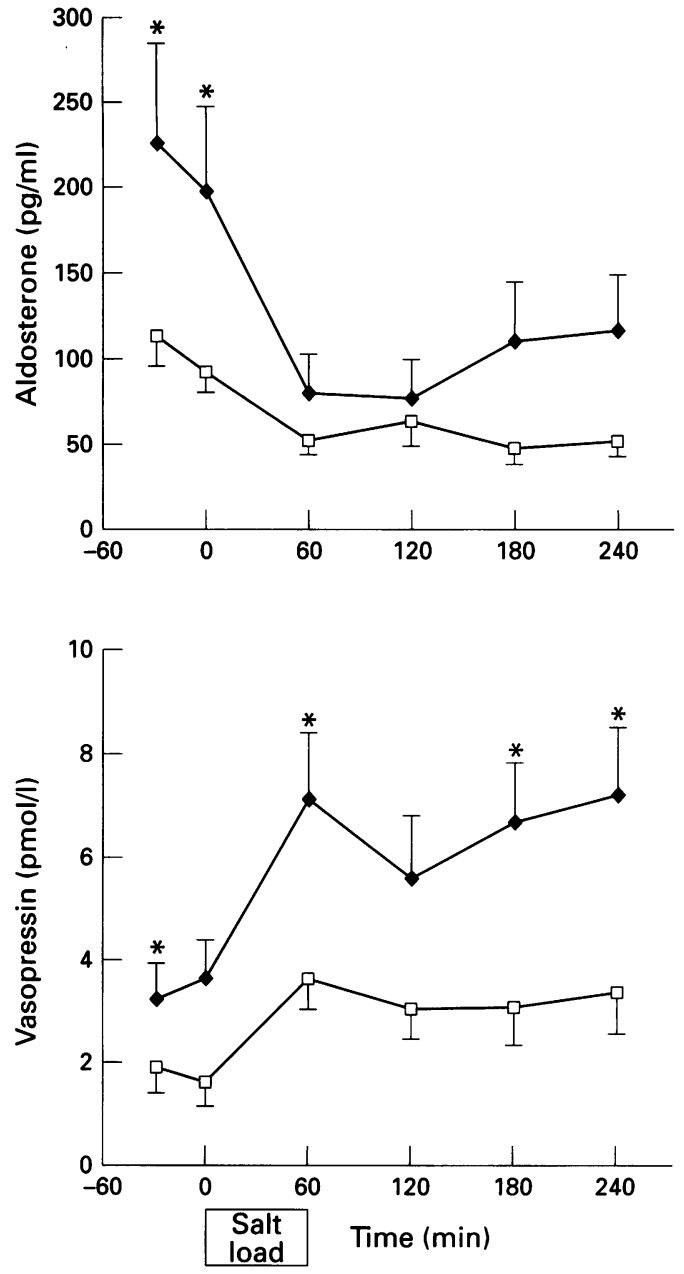

Figure 3 Mean (SE) plasma levels of aldosterone and vasopressin during saline loading in patients with COPD. $\square=$ patients with normal autonomic function $(n=13)$, = patients with autonomic dysfunction $(n=11)$. $* p<0.05$.

loading showed that the $30: 15$ ratio was the most significant $(t=5.9, p<0.001)$ and only renal blood flow $(t=2 \cdot 5, p<0.05)$ was also significant. For urinary volume only the $30: 15$ ratio reached significance $(t=4 \cdot 2, p<0 \cdot 001)$.

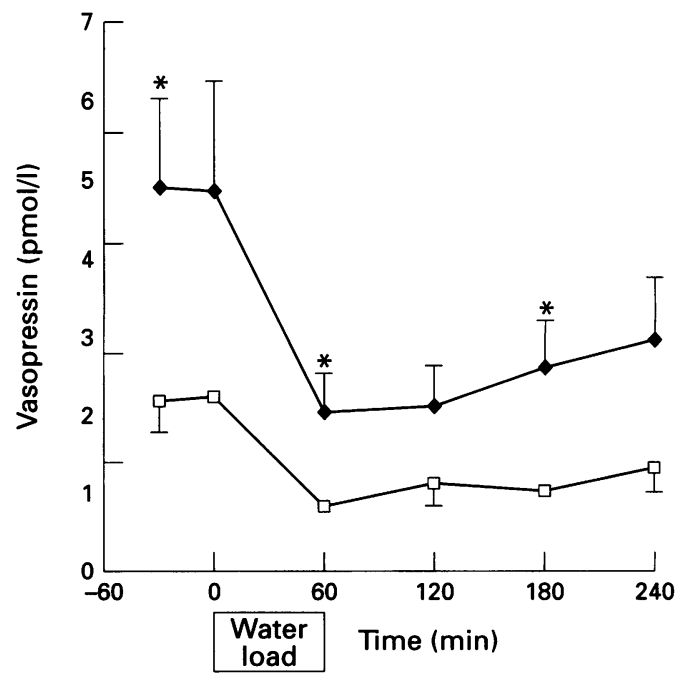

Figure 4 Mean (SE) plasma levels of vasopressin during oral water loading in patients with COPD. $\square=$ patients with normal autonomic function $(n=13),-=$ patients with autonomic dysfunction $(n=11) .{ }^{*} p<0.05$.

\begin{tabular}{|c|c|c|c|c|}
\hline Parameter 1 & & Parameter 2 & $r$ & $p$ \\
\hline $\begin{array}{l}\text { Saline loading: } \\
\text { Sodium excretion }\end{array}$ & $v$ & $\begin{array}{l}\text { Arterial oxygen tension } \\
\text { FEV }_{1} \text { (\% predicted) } \\
\text { Renal blood flow }_{30: 15 \text { heart rate ratio on standing }} \\
\text { Autonomic index } \\
\text { Aldosterone (time } 0 \text { ) }\end{array}$ & $\begin{array}{r}0.71 \\
0.47 \\
0.50 \\
0.77 \\
0.55 \\
-0.52\end{array}$ & $\begin{array}{l}<0.001 \\
<0.05 \\
<0.05 \\
<0.001 \\
<0.01 \\
<0.01\end{array}$ \\
\hline Urine volume & $v$ & $\begin{array}{l}\text { Arterial oxygen tension } \\
\text { FEV }_{1} \text { (\% predicted) } \\
\text { Renal blood flow }_{30: 15 \text { heart rate ratio on standing }} \\
\text { Autonomic index score } \\
\text { Aldosterone (time } 0 \text { ) }\end{array}$ & $\begin{array}{r}0.55 \\
0.55 \\
0.42 \\
0.74 \\
-0.49 \\
-0.52\end{array}$ & $\begin{array}{l}<0.01 \\
<0.01 \\
<0.05 \\
<0.001 \\
<0.01 \\
<0.05\end{array}$ \\
\hline $30: 15$ ratio & $v$ & $\begin{array}{l}\text { Fractional sodium reabsorption } \\
\text { Free water clearance }\end{array}$ & $\begin{array}{l}-0.82 \\
-0.63\end{array}$ & $\begin{array}{l}<0.05 \\
<0.01\end{array}$ \\
\hline $\begin{array}{l}\text { Oral water loading: } \\
\% \text { water load excreted }\end{array}$ & $v$ & $\begin{array}{l}\text { Vasopressin (time } 0,60 \mathrm{~min} \text { ) } \\
\text { Vasopressin (time } 120 \mathrm{~min} \text { ) } \\
30: 15 \text { heart rate ratio } \\
\text { Arterial oxygen tension } \\
\mathrm{FEV}_{1}\end{array}$ & $\begin{array}{r}-0.43 \\
-0.51 \\
0.41 \\
0.58 \\
0.43\end{array}$ & $\begin{array}{l}<0.05 \\
<0.01 \\
<0.05 \\
<0.05 \\
<0.05\end{array}$ \\
\hline Autonomic index & $v$ & $\begin{array}{l}\text { Urine volume } \\
\text { Vasopressin (time } 60 \text { ) } \\
\text { Glomerular filtration rate } \\
\text { Free water clearance }\end{array}$ & $\begin{array}{r}-0.42 \\
0.41 \\
-0.47 \\
-0.42\end{array}$ & $\begin{array}{l}<0.05 \\
<0.05 \\
<0.05 \\
<0.05\end{array}$ \\
\hline
\end{tabular}




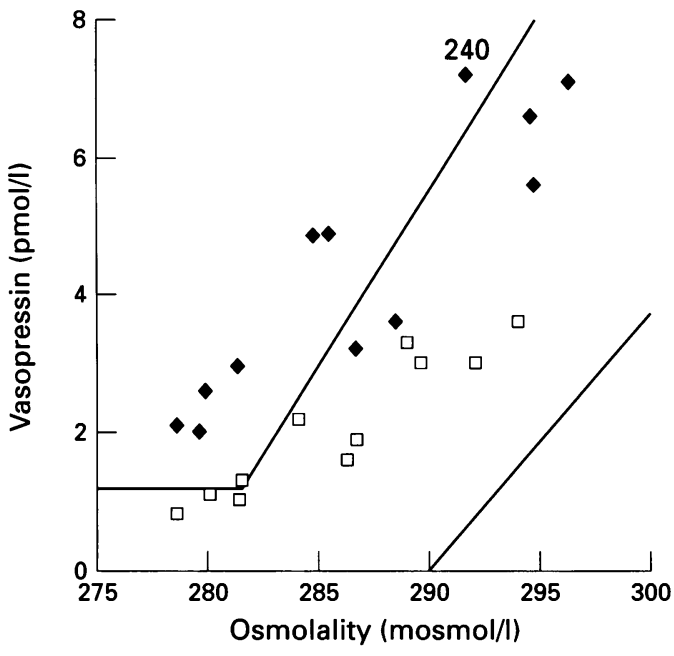

Figure 5 Mean (SE) plasma levels of vasopressin plotted against serum osmolality during the osmolar changes produced by intravenous saline and oral water loading in patients with COPD. $\square=$ patients with normal autonomic function $(n=13), \diamond=$ patients with autonomic dysfunction $(n=11)$. Values between lines are normal.

During the water load only vasopressin levels at time 120 were significant $(t=-2 \cdot 4, \mathrm{p}<0.05)$, the $30: 15$ ratio being the second most important factor $(t=2 \cdot 0, p<0 \cdot 1)$ associated with water excretion.

\section{Discussion}

The results of the saline load test performed in an outpatient setting were acceptably reproducible. Our results show that patients with hypoxaemic COPD have an impaired ability to excrete sodium and water loads. Unlike previous studies ${ }^{5617}$ this impairment was related to the severity of hypoxaemia rather than the degree of hypercapnia. The use of $\mathrm{PaO}_{2}$ to differentiate between groups might have biased this. However, the lack of association between sodium and water excretion and $\mathrm{PaCO}_{2}$ raises questions as to whether some of the earlier reports were confounded by concomitant oxygen therapy which would have raised both $\mathrm{PaO}_{2}$ and $\mathrm{PaCO}_{2}$. The reduction in sodium and water excretion is unlikely to be due to hypoxaemia alone as it is not seen in chronically hypoxic high altitude dwellers. ${ }^{18}$

The results in our control group were similar to those obtained in normal subjects ${ }^{19}$ and in those with mild COPD. ${ }^{5}$ Patients with COPD with more severe disease developed an impaired ability to excrete sodium and water with an increased fractional sodium reabsorption even before they developed oedema. They had apparently preserved renal and endocrine function but did show evidence of a developing subclinical autonomic neuropathy.

Oedematous patients had a significant inability to excrete sodium and water loads. There was a decline in renal blood flow and glomerular filtration rate, together with the development of a subclinical autonomic neuropathy and a small increase in plasma aldosterone and vasopressin levels. The results in the autonomic neuropathy group were similar to those seen in patients with oedema.
This is the first report of an association between the inability to excrete a sodium load and parasympathetic autonomic dysfunction in hypoxaemic COPD. However, a similar diminution in vagal parasympathetic function with preservation of sympathetic tone is reported in congestive cardiac failure ${ }^{20}$ and in alcohol-induced cirrhotic ascites where there is a vagal neuropathy, hyponatraemia, ${ }^{10}$ and an excessive secretion of vasopressin.

Autonomic dysfunction could be important. In animal models cervical vagotomy abolishes diuresis $^{21}$ and natriuresis. ${ }^{22}$ The increased tubular reabsorption of solute-free water produced by interruption of the parasympathetic afferent pathways is mediated by increased levels of vasopressin. ${ }^{23}$

The autonomic function test that best associates with the impairment in sodium and water handling is the baroreceptor-mediated heart rate response to standing (30:15 ratio). This supports the observation that patients with hypoxaemic COPD have a reduced baroreceptor sensitivity. ${ }^{24}$

The parasympathetic nervous system is not believed to have a direct effect on renal function. However, arterial baroreceptor function might regulate sympathetic tone. Interruption of the vagus in the neck of rabbits causes a significant increase in renal sympathetic nerve activity with abolition of the reflex fall in sympathetic tone associated with an increase in effective blood volume. ${ }^{25}$ Our hypertonic saline load would be expected to increase the effective blood volume transiently. A failure to interpret this increase correctly could partly explain the impaired sodium excretion. More detailed study of autonomic and baroreceptor function is needed to determine its importance in the sodium and water retention seen in patients with COPD.

Although plasma aldosterone levels were higher in the oedematous patients before the experiments, most of the results were within the normal range and responded appropriately to saline and water challenges. Furthermore, angiotensin converting enzyme inhibition does not improve the chronic impairment in sodium excretion seen in patients with COPD. ${ }^{7}$ This suggests that stimulation of the renin aldosterone system is not the main cause of the failure to excrete sodium. The slightly raised aldosterone levels ${ }^{45}$ might be a consequence of stress, increased sympathetic tone, ${ }^{8}$ reduction in renal perfusion, alteration in intrarenal haemodynamics, or diuretic therapy. The association of baseline plasma aldosterone levels with sodium excretion and fractional reabsorption might reflect increased renal sympathetic tone. ${ }^{8}$ Renal nerve activity may interact with the prevailing intrarenal pressure to modulate the release of renin. ${ }^{26}$

Plasma vasopressin levels tended to be higher in the oedematous patients and were significantly higher in the group with autonomic dysfunction. Most measurements during the hypertonic saline load test were within the normal limits for serum osmolality, the exception being at 240 minutes in both the autonomic dysfunction and oedematous groups. 
This accentuated prolonged rise in plasma vasopressin levels in response to the hypertonic saline load is similar to that seen in baroreceptor denervated animals. ${ }^{27}$

During conditions of hypo-osmolality induced by the water loading, vasopressin levels were above the expected range in the more oedematous and autonomic dysfunctional patients. The fall in vasopressin levels on lowering serum osmolality suggests that, although its secretion is still under osmotic control, nonosmotic factors play an important part in maintaining raised levels in the more hypoxaemic oedematous patients. This resetting of the osmoreceptor threshold is also seen in congestive cardiac failure and cirrhosis. In patients with congestive cardiac failure it is believed that the reduction in cardiac output ${ }^{28}$ is sensed by ventricular receptors (high pressure receptors in the carotid sinus and aortic arch) as a reduction in the apparent effective blood volume. The decreased afferent impulses to the hypothalamus via the mid brain increases vasopressin release. In patients with cor pulmonale cardiac output is normal. ${ }^{23}$ However, the reduced neural traffic caused by a vagal and glossopharyngeal neuropathy could be interpreted centrally as a reduction in circulating effective blood volume. This would increase vasopressin release and stimulate sympathetic drive. Such a possible mechanism is suggested by the association between baroreceptor autonomic dysfunction (30:15 ratio) and the raised vasopressin levels seen in the more hypoxaemic patients.

The poor correlation between vasopressin levels and urine volume suggest that the raised levels of vasopressin are not the sole explanation for the observed impairment in water excretion. Likewise, the impaired excretion of water and sodium in patients with COPD is not due to a failure of secretion of atrial natriuretic peptide ${ }^{29}$ or brain natriuretic peptide. ${ }^{30}$

Renal blood flow was significantly reduced in the oedematous patients. The results in the control group and those without oedema were similar to the quoted normal range of 16.5 $22.5 \%$ of cardiac output seen in healthy young adults. ${ }^{14}$ The decline in renal blood flow with severity of hypoxaemia, and its association with impairment of sodium and water load excretion, ${ }^{4}$ is in accordance with previous studies. ${ }^{31} 32$

The reduction in the glomerular filtration rate in the oedematous group was less significant. Although most studies have failed to show a significant decline, the glomerular rate does tend to be lower in oedematous patients. ${ }^{183132}$ Although this group was at the lower limit of normal (range $60-110 \mathrm{ml} / \mathrm{min}$ ), only one patient had a glomerular filtration rate of less than $50 \mathrm{ml} / \mathrm{min}$ and no patient had a raised serum creatinine level. These values are unlikely to cause significant renal impairment or to account for the degree of salt and water retention. The greater reduction in renal blood flow than in glomerular filtration rate increases the filtration fraction, raises peritubular colloid oncotic pressure and, thus, might be one explanation for the observed increase in tubular sodium reabsorption. ${ }^{4}$
Our oedematous patients had the greatest fractional reabsorption of sodium and a less negative free water clearance. The increased sodium reabsorption at the proximal tubules limits the volume of urine and solute delivered to the more distal segments where free water is generated for excretion. A similar mechanism may account for the sodium and water retention seen in cirrhotic ascites ${ }^{33}$ and congestive cardiac failure. ${ }^{34}$ Although diuretic-induced sodium depletion reduces the excretion of a water load by the same mechanism, ${ }^{33}$ this is unlikely to account for our results. No patients were hyponatraemic, diuretics were stopped for three days before the test, and the results in the five patients on diuretics were similar to their fellow group members (results not shown). Alternatively, the increased sympathetic nerve activity seen in patients with $\mathrm{COPD}^{35}$ may directly increase fractional sodium reabsorption and sodium retention via a proximal tubular effect. ${ }^{36-38}$

In conclusion, patients with severe COPD have an impaired ability to excrete sodium and water which, in this study, was associated with severity of hypoxaemia rather than degree of hypercapnia. The failure to excrete sodium and water may be multifactorial. Sodium and water homeostasis involves an interplay of hormonal, neural, and vascular mechanisms. The pathological process which occurs in severe COPD upsets this regulation and leads to a perturbation in the many factors involved. In an individual one or other of these factors may be the most important. A fall in renal blood flow and the development of a subclinical parasympathetic autonomic neuropathy, particularly that part involved with baroreceptor function, might be important. A reduction in glomerular filtration rate and small elevations of aldosterone and vasopressin levels might contribute, but their role as major causative factors is unclear. This is the first study to associate autonomic nerve dysfunction with impairment of sodium and water excretion in cor pulmonale. The importance of this homeostatic process warrants further investigation.

1 Renzetti AD, McClement JH, Litt BD. The Veterans Administration Cooperative Study of Pulmonary Function III. Mortality in relation to respiratory function in chronic obstructive pulmonary disease. Am F Med 1966;41:11529.

2 Macnee W. Right ventricular function in cor pulmonale Cardiology 1988;75:30-40.

3 Middleton HL, Peak MD, Howard P. Hypoxaemia in chronic obstructive bronchitis. Thorax 1979;34:213-6.

4 Farber MO, Roberts LR, Weinberger MH, Roberston GL, Fineberg NS, Manfredi F. Abnormalities of sodium and water handling in chronic obstructive lung disease. Arch Intern Med 1982;142:1326-30.

5 Farber MO, Kiblawi SS, Strawbridge RA, Robertson GL. Studies on plasma vasopressin and the renin angiotensin aldosterone system in chronic obstructive lung disease. $\mathcal{F}$ Lab Clin Med 1977;90:373-80.

6 Farber MO, Manfredi F. Mechanisms of hyponatremia and edema in chronic obstructive pulmonary disease: clinical edema in chronic obstructive pulmonary disease:
significance. Practical Cardiol 1984;10:105-31.

7 Stewart AG, Waterhouse JC, Billing CG, Baylis P, Howard $P$. Effects of angiotensin converting enzyme inhibition on sodium excretion in patients with hypoxaemic chronic obstructive pulmonary disease. Thorax 1994;49:995-8.

8 Taher MS, McLain LG, McDonald KM, Schrier RW. Effect of beta adrenergic blockade on the renin response to renal nerve stimulation. F Clin Invest 1976;57:459-65.

9 Bersentes TJ, Simmons DH. Effects of acute acidosis on renal haemodynamics. Am $\mathcal{F}$ Physiol 1967;212:633-40.

10 DeCaux G, Cauchie P, Soupart A, Kruger M, Delwiche F Role of vagal neuropathy in the hyponatraemia of alcoholic cirrhosis. Br Med f Clin Res 1986;293:1534-6. 
11 Stewart AG, Waterhouse JC, Howard P. Cardiovascular autonomic nerve function in patients with hypoxaemic COPD. Eur Respir ₹ 1991;4:1207-14.

12 Stewart AG, Marsh F, Waterhouse JC, Howard P. Autonomic nerve dysfunction as assessed by the acetylcholine sweatspot test in chronic obstructive pulmonary disease. Eur Respir f 1994;7:1090-5.

13 Rooke P, Baylis PH. A new sensitive radimmunoassay for plasma arginine vasopressin. $\mathcal{f}$ Immunoassay 1982;3:11531.

14 Peters AM, Gunasekra RD, Henderson BL, Lavender JP, De Souza M, Ash JM, et al. Noninvasive measurement of blood flow and extraction fraction. Nucl Med Commun 1987;8:823-37.

15 Ewing DJ, Clarke BF. Diagnosis and management of diabetic autonomic neuropathy. BMF 1982;285:916-8.

16 Bland JM, Altman DG. Statistical methods for assessing agreement between two methods of clinical measurement. agreement between two
Lancet $1986 ; \mathrm{i}: 307-11$.

17 White RJ and Woodings DF. Impaired water handling in chronic obstructive airways disease. BMf 1971;2:561-3.

18 Heath D, Williams DR. Man at high altitude. Edinburgh Churchill Livingstone, 1981.

19 Farber MO, Weinberger MH, Robertson GL, Fineberg NS The effects of angiotensin converting enzyme inhibition on sodium handling in patients with advanced chronic obstructive pulmonary disease. Am Rev Respir Med 1987, 136:862-6.

20 Saul JP, Arai Y, Berger RD, Lilly LS, Colucci WS, Cohen RJ. Assessment of autonomic regulation in congestive cardiac failure by heart rate spectral analysis. Am $\mathcal{f}$ Cardiol 1988;61:1282-99.

21 Perlmut JH. Effect of vagotomy on renal function during water diuresis. Proc Soc Exp Biol Med 1964;116:270-6.

22 Vatner SF, Manders WT, Knight DR. Vagally mediated regulation of renal function in conscious primates. $A m \mathcal{F}$ Physiol 1986;250:H546-9.

23 Schrier RW, Berl T. Mechanism of antidiuretic effect associated with interruption of parasympathetic pathways. $f$ Clin Invest 1972;51:2613-20.

24 Patakas D, Lourides G, Kakavelas E. Reduced baroreceptor sensitivity in patients with chronic obstructive airways disease. Thorax 1982;37:292-30.

26 Weekley LB. Angiotensin acts centrally to alter renal sympathetic nerve activity and the intrarenal renin-angiotensin system. Cardiovasc Res 1991;25:353-63.

27 Morris M, Alexander N. Baroreceptor influences on oxytocin and vasopressin secretion. Hypertension 1989;13:110-4.

28 Bichet DG. Water disturbance in cardiac failure. Ballieres $\mathfrak{f}$ Endocrinol 1988;3:559-74.

29 Stewart AG, Bardsley PA, Baudoin SV, Waterhouse JC, Morice AH, Howard P. Changes in atrial natriuretic peptide levels during intravenous saline infusion in hypoxic cor pulmonale. Thorax 1991;46:829-34.

30 Sheedy W, Stewart AG, Morice AH. ANP and BNP concentrations during intravenous saline infusion in cor pulmonale. Thorax 1993;48:447.

31 Platts MM, Hammond JDS, Stuart-Harris CH. A study of cor pulmonale in patients with chronic bronchitis. $Q \mathcal{F}$ 16.559-74.

32 Stuart-Harris CH, Mackinnon J, Hammond JDS, Smith WD. The renal circulation in chronic pulmonary disease and pulmonary heart failure. $Q \mathcal{F}$ Med 1956;25:389-405

33 Schedl HP, Bartter FC. An explanation for and experimenta correction of abnormal water diuresis in cirrhosis. $\mathcal{f}$ Clin Invest 1960;39:248-61.

34 Gibson AG, Marshall JC, Lockey E. Assessment of proximal tubular sodium reabsorption during water diuresis in patients with heart disease. Br Heart f 1970;32:399-405.

35 Reihman DH, Farber MO, Weinberger M. Effects of hypoxaemia on sodium and water excretion in chronic obpoxaemia on sodium and water excretion in chro
structive lung disease. $A m \mathcal{F} M e d 1985 ; 78: 87-94$.

36 Bello-Reus E, Trevino DL, Gottschalk CW. Effect of renal sympathetic nerve stimulation on proximal water and sodium reabsorption. $\mathcal{f}$ Clin Invest 1976;57:1104-7.

37 Slick GL, DiBona CGF, Kaloyanides GJ. Role of rena sympathetic nerve activity in the sodium retention of acute renal constriction. Am $\mathcal{F}$ Physiol 1974;226:925-32.

38 Karim F, Poucher SM, Summerill RA. The effects of stimulating the carotid chemoreceptors on renal haemodynamics and function in dogs. I Physiol 1987;292. 451-62. 